Ovio Olaru

Faculty of Letters, Babeş-Bolyai University Cluj-Napoca, Romania olaru.ovio@gmail.com

\title{
NORWEGIAN INNVANDRERLITTERATUR AND THE SPELL OF TRANSNATIONALISM
}

\section{Recommended Citation:}

Olaru, Ovio. "Norwegian Innvandrerlitteratur and the Spell of Transnationalism”. Metacritic Journal for Comparative Studies and Theory 3.2 (2017): https://doi.org/10.24193/mjest.2017.4.07

\begin{abstract}
This paper focuses on the current evolution of Norwegian literature, namely on the branch of Norwegian literary activity that falls within the theoretical frame of 'immigrationist literature' (innvandrerlitteratur). The paper is to be seen as a pledge against the implementation of cultural studies in the field of literary theory when dealing with such works that, through their number, are unrepresentative for a wider literary context. The argumentation relies on the fact that the phenomenon of innvandrerlittertur cannot be fully addressed from a cultural studies perspective, which often tends to produce reductionist claims and thus lead to ready-made conclusions that fail to reveal the inner workings of the literary phenomenon it aims to present. Moreover, such an approach tends to divert the interpreter's attention from the actual literary works and funnel all interest in the direction of politics and extra-literary contexts.
\end{abstract}

Keywords: Norwegian literature, innvandrerlitteratur, transnationalism

\section{Prerequisites for innvandrerlitteratur}

In 2015 alone, Germany took in more than one million refugees from war-torn Syria. This sparked a great outcry in German society and, above all, the problems that arose as a result of this massive displacement, never before seen after the Second World War, raised a critical question about the viability of accommodating and 
integrating such a great number of people and ethnic groups. But in the wake of globalization, even states that do not belong to a certain superregional political entity such as the European Union see themselves obliged to take in immigrants, even if they lack a historical tradition of open borders and do not regard themselves as a multicultural nation. The tendency towards multiethnic development is more or less embedded in the modern world.

In 1975, the Norwegian law operated with four categories: 1. immigrants who have applied and received a job offer in Norway, 2. refugees and other humanitarian cases, 3. family reunions and 4. International students. While those who sought a job in Norway and those who have applied to study in Norway were to be seen as regular immigrants, in the sense that their decision to come to Norway did not impose itself as a necessity or as the result of life-threatening circumstances, the other demographic groups fled to Norway either as a form of political exile or because the conditions in their country of origin made life there impossible. Within this paper, all four groups fall under the incidence of the term 'immigrant', in the sense that this demographic group is largely understood as having a foreign background, whether or not it has already become fully integrated. Correspondingly, in the statistical data offered by the Norwegian Bureau of Statistics, only the first and second generation of immigrants are registered as such, the others being already regarded as fully integrated in Norwegian society.

In 2004, 8\% of Norway's population was represented by immigrants. This designated a group of 365.000 people, of which 301.000 were immigrants of the first generation, while another 64.000 were born in Norway, but had foreign parents. Even if the people in question had resided in Norway for more than 7 years and had received citizenship, they were registered as immigrants in light of their background. From 1977 up until 2004, 155.000 people had received Norwegian citizenship, out of which more than 130.000 were of non-European origins. Regarding the ethnic distribution of immigrants, 28\% came from Western Europe, North America and Oceania, while the remaining $72 \%$ originated from South and Central America, Africa, Asia (including Turkey) and Eastern Europe. Of all the Norwegian cities, Oslo had - and still has - the greatest percentage of inhabitants of foreign descent, with 118.300 people or $22,3 \%$ of its entire population. Statistically speaking, in 2004, the most immigrants originated from Pakistan, unsurprisingly followed by Norway's 
neighbors, Sweden and Denmark, then Iraq, Vietnam, Somalia, Bosnia-Herzegovina, Iran and Turkey.

The question of immigration has consequently become a controversial topic of discussion in Norwegian politics. Admittedly, $8 \%$ of the country's population cannot be ignored, yet the importance of the subject lies in the fact that immigrants used to represent 22,3\% of Oslo's population, precisely because Oslo is Norway's administrative and political capital. In March of 2000, the Pakistani Shabaz Tariq, belonging to one of Norway's strongest political parties, Arbeiderpartiet, became a permanent representative in the Parliament and the first Member of Parliament from a non-Western country. Now, every one of Norway's political parties with the exception of Fr.p. (Framskrittspartiet, a party with strong conservative roots) has at least one member with immigrational background. In the school year 1992/1993, the Central Bureau for Statistics registered 10.045 pupils who attended either bilingual classes or classes taught in a foreign language. For the school year 2004/2005, this number had almost doubled to 19.713. (Vaagan 25). The integration effort made by Norway is most visible in the case of non-Western refugees, where English as a second language is not an option. In 2004 alone, regional libraries all over the country allotted a total of 300 hours per person, over a period of two to three years, for courses of Norwegian language and cultural integration. This amounts to 37,5 hours a week for every registered refugee. To put these numbers into perspective, the average workweek for someone working a 9-to-17 job amounts to 40 hours.

All the statistics above are from 2005, yet the immigration trend is still on the rise. As of 1 January 2017, the Norwegian Statistisk Sentralbyra registered that immigrants represent $13,8 \%$ of the entire Norwegian population (with 724.987 people), while an additional $3 \%$ were born and raised in Norway, but have an immigrational background. By far, the most significant group is represented by immigrants from Poland, with nearly 100.000 people, followed by Lithuania, Sweden, Somalia, Germany, Iraq and Syria ${ }^{1}$. The statistical distribution has significantly changed, yet immigration still represents a powerful force behind the demographical dynamic of modern-day Norway.

\section{Innvandrerlitteratur}

${ }_{1}$ All statistics presented here were taken from the records of Statistisk Sentralbyrå and can be consulted on http://www.ssb.no/innvandring-og-innvandrere/nokkeltall. 
The evolution of immigrant literature in Norway cannot be dissociated from the evolution of the immigrant phenomenon on the entire Scandinavian Peninsula. Clearly, the evolution and reception of innvandrerlitteratur in Sweden have followed the same trajectory as in Norway and Denmark, yet significant differences can be seen. Far from being interchangeable, the works that have been regarded as belonging to the genre have been received differently by their corresponding readerships, and the reception closely mirrors the political status-quo of the country in question, namely whether or not it is a member of the European Union, or whether or not it has sought to promote immigrant literature in light of a state policy on multiculturalism.

Not surprisingly, Sweden was the first Scandinavian country to open the gates of its literary republic to migrant literature; it happened around 1970. In the case of Norway, it was around the mid-1980s, and in Denmark, the late 1980s to the early 1990s. (Frank 178)

All the papers that have been published on the subject present Sweden as the first country to be listed as a promoter of innvandrerlitteratur, precisely because out of the three Nordic countries in question it has the longest tradition of multiculturalism. As Ingeborg Kongslien, professor emeritus at the Institute for Linguistic and Nordic Studies at the University in Oslo, author of numerous articles and studies on Nordic immigration literature, remarks:

Unsurprisingly, Sweden has the longest history as well as the largest output of this new literary tradition, which conforms to the features of the immigration processes in the Nordic countries. Scholarly attention to this field is also led by Sweden, with a thoroughly researched and well-written study that treats the subject both sociologically and thematically. (Kongslien)

When talking about migration in regard to Norwegian literature, Søren Frank uses the example of Jan Kjærstad. Without being a migrant author himself, he has lived for several years in Zimbabwe, thus his style and Weltanschauung has supposedly borrowed stylistic and structural elements traditionally associated with migrant literature. Søren Frank’s book Migration and Literature can easily serve as a relevant example for the conceptual difference between immigration literature and migration 
literature, between the so-called innvandrerlitteratur and migrasjonslitteratur. While the former refers to literature written by immigrants who setteld in Norway and Sweden, the latter applies to literature written by migrant authors such as Jan Kjærstad. Nevertheless, parallels between the two can be drawn stemming from the transnational character of both their aesthetics and the intercultural conflicts or narratives of peaceful collaboration that they illustrate. His argument is that

"[T]raditional" migrant literature written by migrants (this generalization should of course be taken with all kinds of precautions) - combined with the globalizing forces in contemporary society-has made an immense impact on literature in general. Hence, literature written by nonmigrants can in some cases be likened to migrant literature in terms of both form and theme. (Frank 180)

Similarly, literature that cannot technically be called immigrational bears a resemblance to literature written by immigrants, to the extent that it dwells on the same issues and reflects the same collective mentalities. For example, Frank A. Jensen's first novel, published in 1981, Salbingen (The salt bin)2 ${ }^{2}$, tells the story of the Saami Agnar, who grows up in a little village from Tysfjord in northern Norway during the ' 50 s and the "6os. The novel's main theme is racism against the Saami people, who see themselves both culturally isolated because of their seemingly exotic way of life and forcefully integrated into the Norwegian economic circuit. Living in poverty, competing for fishing spots or striving to find work in one of the state-owned factories, Agnar and his wife Lisa represent two different takes on the problem of cultural conflict within the same country. While Agnar attempts to overcome his humble origins and become a full-righted citizen through hard work, Lisa revolts against Norwegian hegemony and strives to retain her Saami specificity. Situated between these two competing approaches to negotiating identity, their son Petter retains his mother's pride and obstinacy in dealing with a Norwegian milieu hostile to the Saami people: „Æ kan ikke les, og boka e vesstnok skreve på tysk også, men mange sei at den boka vis at vi sama e dårligar enn andre folk."3 Albeit this novel cannot be regarded as representative for innvandrerlitteratur per ser, it possesses the same structure and thematic interest.

2 Information regarding Saltbingen was taken from the author's official internet page, http://www.frankajenssen.no/boker/ (20.10.17)

3 "I can't read, and the book is in German anyway, but there are many who say that we Sami are worse than other folk”. See Frank A. Jenssen, Saltbingen. Aschehoug Forlag, Oslo, 1981. 
The fact that Norway does not belong to the Union, nor does it seem eager to apply for membership, has been a huge setback for the evolution of the genre within Norway, despite the perhaps more relevant fact that more than $13 \%$ of Norway's population is foreign. The lack of literary representation for precisely this sociological group has meant that many of the works labelled as immigrant literature have reached the Norwegian readership either through translation into Norwegian, or by being published in Swedish or Danish. Due to the relatively common social and cultural environment of the three countries and the practically inexistent language barrier (Norwegians can easily read both Swedish and Danish), as well as to the availability of Scandinavian literature within the peninsula, immigrant literature from Sweden can be regarded as an exemplary instance of Scandinavian immigrant literature: its reception is definitely richer than in Norway or Denmark, but the conclusions that can be drawn from it are basically the same. Jonas Hassen Khemiri's Et øye rødt (A red eye) was first published in Swedish and translated into Norwegian Bokmål in 2005. Upon publication it was praised for its particular use of language as "en smart och hjärtevarm roman som drattar språket på ända och får svenskan att glänsa som om den vore ny".4 The novel raises questions about identity negotiation, the struggle of bilingualism and the difficulties of integration. The novel's protagonist, the schoolboy Halim, retrospectively declines integration - albeit already integrated - and refuses to renounce his Arabic character and idiosyncrasies - which he has not even had the chance of experiencing, having been born in Sweden. His plan is to become a Sultan, his ambitions naïve, his language a mélange of Swedish and Arabic lingo, characterized by strange syntax and spontaneous linguistic inventions. In this sense, the book bears similarities with the German-Turkish literary production, especially with Feridun Zaimoglu's novel Kanak Sprak. 24 Mißtöne vom Rande der Gesellschaft, a book that coined the concept of Kanak Sprak, the exotic mix of German and Turkish spoken by second generation Turkish immigrants. But while Zaimoglu's use of Kanak is political to the extent that it reflects the disappointment and frustration of being unable to integrate due to linguistic barriers, Khemiri's use of language conveys nothing more than the fear of losing one's specificity. Young, resourceful and a speaker of perfect Swedish, Halim goes back to

\footnotetext{
4 ,an intelligent and heart-warming novel that reinvents the Swedish language and makes it shine as if it were new" (Kamlteg). See Kamlteg, Lina, Debutantpris till Khemiri, 05.03.2004, Dagens Nyheter Online, https://www.dn.se/arkiv/kultur/debutantpris-till-khemiri.
} 
his Arabic roots under the childish fascination with Orientalism. Et øye rødt bears the structure of a diary, in which every petty act of subversion in regard to the Swedish language or norms is celebrated as a victory over the projected authoritarian figure of Swedish society. Halim's father is a fully integrated Moroccan from the first generation, who regards his son's revolt as nothing more than teenage rebellion, but whose acceptance of Swedish values infuriates Halim and validates his quest of rebecoming Arab. (Morten) The novel is interesting, because it reverses the general tendency of immigrant familial settings, in which the first generation finds it hard to integrate or obstinately refuses to do so, in the naïve hope of someday returning home, while the second generation, integrated, but still capable of keeping a borderline contact with its original language, showed nothing but contempt and condescendence towards the generation of the elders. As Seyhan points out,

The immigrant parents cling to a language on which their children have only a tenuous and disintegrating hold. Their cultural habits are ingrained and allow for no recasting. The burden of refashioning cultural practices to avoid embarrassment and misjudgment falls on the children. (Seyhan 74)

Admittedly, the aforementioned examples do not strictly reflect Norwegian innvandrerlitteratur, but they provide a necessary context for its appearance and development, in the sense that the themes and motifs the genre is prone to use were not at all foreign to the Norwegian readership. Khalid Hussain's novel Pakkis, published in 1986, which in the meantime has become a part of the academic canon, is considered the first example of purely Norwegian immigrant literature. The book tells the story of a young 15-year-old immigrant, Sajjad, who has to constantly shift between his Pakistani home and his Norwegian life outside the confines imposed upon him by a strong paternal figure and Islamic rules. His struggle is based on the contradiction between cultural inheritance and developed identity. This constant negotiation proves difficult enough on its own, but encounters an escalation when his father shows the intention of sending him back to Pakistan in order to marry him away. Despotic and breeding a feeling of entitlement towards his son, the father symbolizes the rigors of a culture so exotic to the liberal familial milieu of Norwegian society that it becomes opaque. Perhaps the book owes its popularity to the fact that it makes no compromise in favour of public-oriented writing, in the sense that Hussain, 
having published Pakkis at the age of sixteen, was not aware of the expectations of the Norwegian readership and of the preconceptions regarding migration and immigrants. His simple, yet naïve and down-to-earth style lacked any sort of political undertones that would have led to the false conclusion that the novel possessed a militant background or program.

Romeo Gill's novel, Harjeet, was published in 2008 and was followed shortly after by Ung mann I nytt land (Young man in a new land). The two books were read as a series, although they can also function independently. Harjeet tells the tale of a young Indian who travels to Norway to pursue a well-paying job in a factory, leaving behind his wife and two boys, Akas and Sorj, age seven and nine. The plan is to return to India after a period of two years. Simultaneously, the story follows the familial milieu in Punjab, near the border to Pakistan, the struggles and resentments bred within the seemingly abandoned household. On the other hand, Ung mann I nytt land is situated in Drammen in Norway, where, four years later, in 1977, Harjeet succeeds in reuniting his family. The wife and two sons move together with the slightly alcoholic, patriarchal and despotic father. Even if this second novel aims to create a larger perspective, it mostly focuses on the development of the younger son Akas, borrowing his narrative point of view in light of the entire family's efforts of integration. Unsurprisingly, the novel becomes a Bildungsroman, and the case of Akas becomes representative for the entire second generation of immigrants residing in Scandinavia. (Sørbye).

Heidi Marie Kriznik's debut novel, Applaus, is one that focuses on Polish immigration, dwelling on issues regarding memory and nostalgia. The Norwegian Eva Nordhaug, in her novel Saynab, borrows the point of view of a Somalese immigrant. In the same way, Bryniulf Jung Tjønn uses a South Korean point of view in his novel Kinamann (Chinaman), published in 1983, when telling the story of a small Chinese boy raised in Norway from the age of three. Another book that deals with nostalgia and whose Norwegian setting serves as pretext for the revival of exotic narratives is Roda Ahmed's Forberedelsen (The preparation), whose protagonist, Zara, was born and raised in Norway, but finds comfort in her grandmother's ample recounting of Somalia. Maria Navarro Skaranger writes in her debut novel, Alle utlendiger har lukka gardiner (All foreigners have their curtains drawn), about isolation and shame. The protagonist's older brother is in prison, her younger brother is confined at home. I morgen ler vi (Tomorrow we laugh, 2016) is another debut by 
Namra Saleem dealing with issues of shame and resentment. Samina, having had a child with a non-Muslim Norwegian man, sees herself cut out from her family, who then spread the rumour within the Pakistani community that she had died. She returns to her family alongside her five-year-old daughter, Selma.

These examples, even if they do not represent an exhaustive introduction to innvandrerlitteratur, are sufficient for illustrating a certain tendency and offer an insight into the prevalent structures that dominate the phenomenon. This paper does not set about to compensate for the lack of studies dedicated to the Norwegian immigrational literature, quite the contrary. The argumentation benefits from the fact that innvandrerlitteratur has not been studied enough and thus has not been subscribed to any theory, namely because this would have led to its inclusion into the Norwegian contemporary literary canon, already perverted by a very specific set of hermeneutical instruments, which is the case with Swedish immigrant literature.

Literary studies, alongside studies that propose a deeper insight into the phenomenon of immigrational literature almost exclusively make use of concepts such as World Literature, transnational and multicultural literature. The applicability of these concepts is rarely denied. Admittedly, they allow a whole range of methodological operations. They apply to politics, sociology, visual arts, and last, but not least, literature. It would be hard to imagine Swedish politics, for example, without addressing transnationalism. The country's project of mass immigration and efforts of integration would be inconceivable without a sturdy conceptual framework. The modern world is a globalized space, and consequently its understanding requires disowning obsolete and reductionist claims such as the existence of culturally monolithic nation-states, homogenous ethnic unities, immovable borders and the great narratives of national histories. This is exactly what these concepts set out to create: a space of continuous dialogue, of undisturbed transfer and decentred influence, fuelled by heterogeneous sources, but foremost by its own directionless movement, outgrowing the confines of the purely national and defining itself not in opposition to something else which it aims to replace. As Arjun Appadurai observes,

The wave of debates about multiculturalism that has spread through the United States and Europe is surely testimony to the incapacity of states to prevent their minority populations from linking themselves to wider constituencies of religious or ethnic affiliation. These examples, and others, suggest that the era in which we could assume 
that viable public spheres were typically, exclusively, or necessarily national could be at an end. (Appadurai 22)

When a structural coherence is to be found, it is seen as a spontaneous convergence of aesthetics rather than a group unified by a militant desire to revolutionize a certain field. This partly corresponds to the fulfilment of the enlightenment project of universal tolerance and acceptance, not only in regard to the Other, namely not exclusively in terms of alterity, but also when dealing with opposing artistic or literary programs or aesthetics.

There is, however, a question to be asked, namely which are the measures that these approaches have taken in order to avoid an interpretative trap? Which is the factor that vouches that, in dealing with transnational phenomena, the interpretation goes beyond the level of political discourse? What guarantees that a book, regardless of what kind of clash between cultures it tries to illustrate, of the undertones it tries to bring to light, of the racism it tries to denounce, or the attempt to provoke the readership through renouncing the prevalent norms of political correctness, is indeed a piece of good writing? The concept that comes under my scrutiny is immigration literature' under several of its forms of expression, especially in the Scandinavian literary context: Innvandrerliterattur or migrasjonsliteratur. While the former focuses on literature written by immigrants regardless of its themes and focal points, the latter applies to literature that tackles issues of migration and integration, of travel and migrant identities. While the two may not necessarily overlap, innvandrerlitteratur often has the tendency of dealing with themes that recommend it as literature of migration and falls within its paradigm.

\section{What are the problems of innvandrerlitteratur?}

Firstly, the term 'immigration literature' is almost exclusively used to describe literary phenomena whose origins can be traced outside the Western World. The main reason for this is the fact that the concept of 'immigration' has come to symbolize the displacement of people from Second and Third World countries, to nations that can be referred to as First World. Profiting from the opening of the labour market in the country of destination or pursuing preconceptions of a welfare myth developed in the country of origin about the First World (either the 'American Dream', the myth of German efficiency or, in the case presented in this paper, the 
Scandinavian 'velstandssamfunn'), these displacements have contributed to the fact that immigration is less bound to transnational subjects within the First World than it is to either the politically grounded exile or the capitalist dynamic of global inequality. In his introduction to world-systems theory Immanuel Wallerstein argues that the core nations of the world differ in terms of economic growth, cultural status and general welfare from the nation-states belonging to peripheral or semi-peripheral zones. In this sense, he denounces the imbalance that subjects many forms of immigrant cultural production to an inferiority complex in regard to host cultures:

Some countries were stronger economically than others (the core) and were therefore able to trade on terms that allowed surplus-value to flow from the weaker countries (the periphery) to the core. Some would later label this process "unequal exchange." This analysis implied a remedy for the inequality: actions by the states in the periphery to institute mechanisms that would equalize the exchange over the middle run. (Wallerstein 12)

Secondly, the concept of 'immigrant literature' exists only to the extent that it brings underlying issues regarding race, ethnicity and exile to light. This can only take place when the contrast between two cultures that come into contact with one other is powerful enough to generate visible cultural conflicts and incongruities that express themselves at a public level. Surely, immigration policy imposes a set of societal changes, political measures and changes in public discourse that enable the cultural accommodation of immigrants, yet these measures do not account for the other discourse, the one of the general public opinion, which is undoubtedly dominant. The German political rhetoric during their entire post-war history of accommodating and integrating Gastarbeiter, for example, was one of tolerance and acceptance, yet this did not prevent racism, alienation and isolation, which ultimately led to the ghettoization of non-Western immigrants in Germany during the ' 90 os. In the Scandinavian Peninsula, this role has been attributed to Scandinavian Noir, a transnational trend that encompasses both Swedish and Norwegian, Finnish and Icelandic crime and thriller authors. Scandinavian Noir is a striking example for the alienating effect of the public discourse, which, under the imperatives of political correctness, seeks to bury all instances of racism and cultural conflict, which then tend to make their way into crime novels within a genre-determined convention. 
Barry Forschaw, commenting on Kurdo Baksi's monography on Stieg Larsson, offers valuable insight into this seemingly exotic means of subverting public discourse:

Kurdo Baksi, author of the memoir Stieg Larsson, My Friend (2010), is convinced that (both for himself and his late colleague) journalism is insufficient to present a complete and rounded picture of society. 'We need other forms of literature,' according to Baksi, 'and crime novels can be a perfect way to paint a picture of social tensions in different countries. For instance, Stieg Larsson was not allowed to write long, in-depth articles about racism, feminism and social injustice in the Swedish newspapers. And that, I think, is the reason why he wrote the Millennium trilogy - which deal with those issues.'

Non-Scandinavian readers, Baksi feels, are being given insights into Nordic society by contemporary crime fiction. Nordic crime writing shows that violence, the ill-treatment of women and endemic racism are components of daily life. (67)

Lastly, the third factor represents the symbolic imbalance between the culture that serves as host and the immigrant culture. Norway does not belong to the European Union, despite the two polls organized on the subject in 1972 and 1994, which illustrated the country's refusal to partake in a political superstructure that would have regulated the way it handled its newly found oil reserves, and despite the formal economic agreements the country maintains with the Union. Thus, Norway has not set the goal of becoming a multicultural nation, nor must it fill a European quota of immigrants. In this case, a comparison with its neighbouring country Sweden is unavoidable. While Sweden maintains a policy of permanent social, cultural and legislative adaptation to its minorities, sometimes breeding dissatisfaction with its native population for being unable to cater to the needs of the common Swede, the Norwegian policies of integration, far from neglecting the innate difference between the foreign immigrant groups and its natives, hold on to the premise that minorities are the ones that should adapt to the dominant culture and, like previously mentioned, put a whole range of services such as language courses and courses in Norwegian civilization at their disposition.

These three factors, although insufficient for giving an exhaustive explanation as to why the term innvandrerlitteratur has come to be used almost exclusively when discussing immigrant literature originating outside the First World, do explain why 
the term has come to bear a negative meaning. Ingeborg Kongslien points out exactly this aspect when she writes:

The terms "immigrant literature" and "immigrant writer" (their respective Scandinavian counterparts, "indvandrerlitteratur/-forfatter" "innvandrarlitterat ur/-forfattar", "invandrarlitteratur/-författare") have turned out to be problematic. Many of the writers dislike these terms because they feel that "immigrant literature" indicates a marginal type of literature and denigrates their artistic ambitions. Despite this, literary scholars, critics, and the media continue to employ the terms, which probably indicates their usefulness, especially when it comes to promoting this writing. (Kongslien)

Not only is innvandrerlitteratur associated with a literature that relates to its Norwegian counterpart and to the literary establishment not as an equal, but as a minor literature, it has also become a label, a mechanism of facile theoretical encasement, offering the interpreter an easy path and simultaneously creating restrictive delimitations. Another problem that appears when discussing immigrant literature regards the authors themselves, who explicably refuse group affiliations and pretences of programmatic or overtly militant writing, but would rather be regarded as Norwegian or Swedish writers, thus accepting their new identity.

\section{Why did innvandrerlitteratur become a marketable label and what are the implications?}

Works of art, bodies of literature and cultural production in general have generally become marketable goods. Far from denouncing this process as unnatural or pernicious to the literary field, in the sense that it diverts any interpretative effort from the purely aesthetical, it is clear that, in the case of immigrant literature, this process incites an implicit competition between the migrant newcomers and a wellestablished, historically stable literary canon. Core states, in the wakes of globalization and permanent cultural transfer within the first world, share a pool of common cultural tropes: their ways of life, their cultural idiosyncrasies and their overall Weltanschauung is relatively homogenized. The agents of such homogenization are diverse, yet market growth, free travel and a set of values largely regarded as Western has led to the paradoxical fact that, for example, Norway and South Korea can more easily communicate from the standpoint of day to day life than 
Norway and Albania could, for example. Norway is undoubtedly a First World country. So is South Korea. Yet Albania does not qualify as such. It is equally clear that Norway and South Korea are culturally incongruent if we choose to regard them in their deeper, historically determined character. So are Albania and Norway, ultimately also Albania and South Korea. But in this case, what matters is not the historically determined, national specific character: their past and their specificity having become 'cultural inheritance', their meeting point remains their globalized interfaces. Norwegians enjoy better meals, afford better clothes and generally thrive in comparison to geographically closer countries, which do not belong to the so-called First World.

These examples are not to be regarded as universally valid and representative for other conjectures. Reductionist as they are, they bear solely the role of illustrating that core states are not only economically intertwined and owe their growth to peripheral or semi-peripheral nations, but are also culturally alike at a superficial level. This is most visible in the case of European authors writing transnationally. A German or French author writing in Swedish would never be regarded strictly as an immigrant author nor would he come under the incidence of innvandrerlitteratur within the host-system of literary criticism. The origin of the author in question would perhaps be discussed, yet it would not prove itself fundamental to the interpretation, nor act as a marker for the innate literary value of the work. Thus, a German writer describing his migrant experiences in regard to a Scandinavian host culture would possess less credibility and would give so familiar an account to his well-travelled Scandinavian readership as to become redundant. In direct contrast, an account given by a Pakistani writer, with its entirely different cultural tropes and inherent social, political and symbolic hierarchies, would offer its readers a totally alien insight.

This state of affairs owes its existence in part to the commercialization of 'difference' and the fetishization of 'identity', which have come to replace any polemic on aesthetical value. Within this fetish, identity is seen as a clear by-product of migrant practices, as a definite end-result and not as a perpetual development. As Stuart Hall argues,

Identity is not as transparent or unproblematic as we think. Perhaps instead of thinking of identity as an already accomplished fact, which the new cultural practices then 
represent, we should think, instead, of identity as a 'production', which is never complete, always in process, and always constituted within, not outside, representation. This view problematizes the very authority and authenticity to which the term, 'cultural identity', lays claim. (Hall 222)

Furthermore, the fetishization of difference implies, to a certain extent, the domestication of the foreign and an implicit effort of subscribing it to preconceived ideas of multicultural identity. Rather than allowing for migrant identities to develop an independent race or class consciousness, nation-states come forward with a prefabricated conceptual framework regarding ethnicity and difference, which, far from being objective and allowing migrant identities to freely unfold, represents a form of control. Under the pretext of catering to migrant needs, nation-states construct a form of symbolic inequality that resembles colonial power plays:

In the multicultural paradigm, where difference is admitted, structural and ideological reasons for difference give place to a talk of immutable differences of ethnic cultures. In both paradigms as the focus shifts from processes of exclusion and marginalization to ethnic identities and their lack of adaptiveness, it is forgotten that these officially multicultural ethnicities, so embraced or rejected, are themselves the constructs of colonial - orientalist and racist - discourses. (Bannerji 9)

A sort of scepticism regarding cultural studies is also expressed by Terry Eagleton, who, in addressing Postmodernism, points out one of its contradictions, namely that, on the one hand, it refuses any sort of distinctions and classifications (reality vs. hyperreality, truth vs. fiction, high culture vs. pop culture), firmly believing in 'closing the gap' and that 'anything goes!' - two of the mottos that have become representative for postmodern though - and, on the other hand, it promotes and encourages difference as a sort of ultimate alternative to the grand (political) narratives discredited by Lyotard. As everything becomes global, politics become localized in trying to address issues that stem from precisely this globalization tendency.

Difference was the new catch-cry, in a world increasingly subject to the same indignities of starvation and disease, cloned cities, deadly weapons and CNN television. It was ironic that postmodern thought should make such a fetish of difference, given 
that its own impulse was to erase the distinctions between image and reality, truth and fiction, history and fable, ethics and aesthetics, culture and economics, high and popular art, political left and right. (Eagleton 46)

Difference has become an asset of symbolic exchange, a currency that found its way into the cultural and political discourse and which has come to unequivocally represent progress, tolerance, openness; in short, every characteristic of the enlightenment project the Western World has tried to put into practice.

Equally important is the persistence of Eurochronology in studying literature. Only in more recent times has this approach been replaced by the attempt of discussing local literary phenomena in terms of a local expression of World Literature. But, as David Damrosch argues in his introductory study on World Literature, the scholars studying The Epic of Gilgamesh limited their interpretative efforts to attempts of finding correspondences with the biblical story of The Flood not surprising, given that the Bible had begun to lose its credibility in light of new geological finds and, most importantly, in light of Darwin's theory of evolution. George Smith, the finder and first translator of the tables that compose the Epic,

viewed the poem chiefly as corroboration for the Bible; he published his first translation in 1874 under the title The Chaldean Account of the Deluge, a title that forthrightly treats the epic as a parallel to the biblical Flood account, even though the story of Utnapishtim takes up less than a tenth of the text and only secondarily involves the epic's true hero. (Damrosch 56).

In much the same way, Damrosch continues, the Aztecs, when faced with the biblical narratives imported by Spanish colonists, did not accept them fully and did not renounce their own symbolic hierarchies, but rather integrated them into their own imaginary system, using the material provided by the Bible in reshaping their own culture in the decades following the Spanish colonization, borrowing mythical structures, but retaining local deities. These two examples provided by Damrosch illustrate that the mechanisms of cultural appropriation and naturalization of foreign elements work both ways. Clearly, they do not constitute the terms of a valid and equal comparison, but rather aim to show that it is not only the Western World that is selective with the cultural material that permeates it, choosing to utilize solely the elements that can be applied to the prevalent Weltanschauung. Admittedly, it is 
redundant to note that bodies of literature so foreign to the Western World have found their way into it firstly by way of corroboration, and that literary critics of the Western World, in their analytical zeal, tried to best fit bodies of foreign literature to their theoretical framework. Immigrant literature is foreign and exotic inasmuch as it complies, on the readership's side, with Western expectations of immigrant experiences. On the other side, the theorists see their concepts regarding immigrant writing confirmed. They live up to the Western World's expectations of them, breeding the consciousness of their own suffering, they import Western sensibilities and write as if they were the embodiment of the Western World's own displaced self in cultural spaces that are as foreign to us as our cultural tropes are for them. They become conscious of their own strangeness because the marketability potential of immigrant literature has made it imperative that this strangeness be maintained and constantly pointed out, whether as racism or fetishization of difference. It is as if host cultures told them: Be yourself! Do your thing! Act natural!

Historical classifications of genre and form are purely European and most often formulated retrospectively, looking back at aesthetic invariables, stylistic advances and generational world-views that have already permeated the literary field and have subsequently made their way into the canon. We can now say with certainty that Modernism, for example, encompasses all the various -Isms prevalent in the first half of the $20^{\text {th }}$ century, even if the writers of the period, lacking the distance and the historic perspective we now possess, were not aware of their own theoretical coherence, as opposed to the pluralistic and often antagonistic present to which they belonged. As Apter points out,

European literatures carry the prestige of print culture (heightened by a special claim on the modern novel), while non-European literatures, subject to Eurocentric standards of literariness and readability that class them closer to folklore and oral culture, tend to occupy a more tenuous position in World Literature. Clearly, the nations that name the critical lexicon are the nations that dominate the classification of genres in literary history and the critical paradigms that prevail in literary worldsystems. (Apter 135)

Immigrants, as they begin to write, borrow poetical and narrative structures innate to European writing. Not only is it a transfer between incompatible literary systems, it is often also a transfer from an oral to a written literature, raising not only problems of 
aesthetic hierarchies, but of incongruent forms and genres. The Bildungsroman can be regarded as typically European, yet Khalid Hussein's Pakkis is precisely that. The narratives which are to be found within innvandrerlitteratur, even when they overtly portray conflicts between Scandinavian culture and immigrant identities, acknowledge the existence of a cultural gap and implicitly validate the need to discuss this gap as such: conflicts implicitly oblige this literature to subscribe to our theories. Emily Apter further argues that, even if one of the prerequisites of World Literature is the existence of a single, equal literary system homogenized by translations, the reference point remains inherently Western:

Discrepant modernisms necessitate the conversion of conventional paradigms of literary history or incite the invention of new ones altogether. As already noted, in Western literary criticism, even when the purview is World Literature, Occidental genre categories invariably function as program settings. And when non-European literatures are addressed, they are often grouped under monolithic rubrics such as "Islam" or "Asia". (Apter 137)

Apter's opinion opposes the prevalent argument of social sciences, namely that literary production precedes its conceptual frame: "Literature as an institution and literary fiction as an expression of human experience predate their theoretical articulation" (Seyhan 7). The appropriation of foreign, non-Western bodies of literature and their critical analysis has always been done by Western standards and with Western ideas of 'literary value', Western ideals regarding composition, and within a European ethical system. Interpretations of immigrant literature confirm preconceptions or mitigate against them, but ultimately fall for the trap of using specific binary oppositions, reducing the works to a simplistic tale of clashing worldviews or peaceful integration. The literary phenomenon of innvandrerlitteratur, as well as Western paradigms of literary hermeneutics such as transnationalism impose a pattern of 'seeing' these dual structures, which makes it impossible for the books to come under an aesthetical reading. The point made by Terry Eagleton is that we are blinded by our own deeply rooted cultural reflexes; in fact, so deeply rooted into our Western consciousness that we became unable to even record their influence, even in the instances when we explicitly set about to overcome them: 
Instead of doing what comes naturally, we do what comes culturally. Instead of following Nature, we follow Culture. Culture is a set of spontaneous habits so deep that we can't even examine them. And this, among other things, conveniently insulates them from criticism. (Eagleton 59)

The books belonging to the genre evade text immanence and fall under the spell of positivism, which solely takes into account their value as sociological documents. Of course, corroboration and mutual influence are inevitable in the case of immigrational literature, like they are in the case of colonial writing:

[I]n cultures that belong to the periphery of the literary system (which means: almost all cultures, inside and outside Europe), the modern novel first arises not as an autonomous development, but as a compromise between a Western formal influence (usually French or English) and local materials. (Moretti 152)

But the literary phenomenon of innvandrerlitteratur present in Norway, too small to become representative for the entire literary production of the country (small in regard to the statistic distribution of the population whose experiences it should or could illustrate), do not deviate from this scheme of binary oppositions. Almost exclusively, the narrators of these works fluctuate between nostalgia and problematic integration, experience longing and frustration, encounter language barriers or racism. Ultimately, these blockages recount narratives of integration. Immigrants are not bound to leave and find themselves under no pressure whatsoever to do so. But at the level of literary production, their works fall victim to massive theoretical confines and reductionist interpretations, that leave out any consideration about their aesthetic dimension and instead focus on the political and sociological conclusions that can be drawn from them. Kongslien, when referring to the new authors of Nordic literature, excludes any consideration regarding their writing, instead emphasizing precisely things that can be easily formulated about any immigrant, whether author or not, and refuses to elaborate on their literary specificity.

The new voices in contemporary Nordic literature are important in terms of identity and integration. The themes of migration and exile, of biculturalism and bilingualism, express the process of acculturation, integration, and identity formation. (Kongslien) 
It can be noted that this scheme is utilized explicitly by the theorists who, having direct contact not only with the literature in question, but also with the sociological background it seeks to describe, ought to be able to discern between the writing per se and multicultural projects pushed forward under the imperative of political correctness. The claim is not that purposely creating such binary oppositions has become a recipe for success on the literary market, but it is clear that the popularity of these books is directly proportional to the degree to which they validate a Western need for theory in dealing with literature. Immigrants evolve to write as Westerners and Western criticism validates their works only inasmuch as they confirm its theories on World Literature, transnationalism and multicultural writing. 


\section{References}

Abrahamsen, Morten, Mellom kjöttbullar og kebab. Jonas Hassen Khemiri: «Et øye rødt», in VG Rampelys, https://www.vg.no/rampelys/bok/musikkanmeldelser/mellom-kjottbullar-ogkebab/a/276729/ (20.10.17).

Appadurai, Arjun. Modernity at large. Cultural dimensions of Globalization. University of Minnesota Press. Minneapolis; London, 1996.

Apter, Emily. Against World Literature. On the politics of untranslatability. Verso, New York; London, 2013.

Bannerji, Himani. The dark side of the Nation. Essays on Multiculturalism, Nationalism and Gender. Canadian Scholars' Press, Toronto, 2000.

Damrosch, David. What is World Literature?. Princeton University Press, Princeton; Oxford, 2003.

Eagleton, Terry. After theory. Basic Books, New York, 2003.

Forschaw, Barry. Death in a Cold Climate. A Guide to Scandinavian Crime Fiction. Palgrave Macmillian, London; New York, 2012, p. 67.

Frank, Søren. Migration and literature. Günter Grass, Milan Kundera, Salman Rushdie, and Jan Kjærstad. Palgrave Macmillian, Hampshire, 2008.

Gill, Romeo. Harjeet. Oktober forlag, Oslo, 2008.

---. Ung mann i nytt land. Oktober Forlag, Oslo, 2011.

Hall, Stuart. Cultural identity and diaspora. In: Theorising diaspora, 2003, pp. 233247.

Hussain, Khalid. Pakkis. Tiden Forlag, Oslo, 1986.

Jenssen, Frank A. Saltbingen. Aschehoug Forlag, Oslo, 1981.

Kamlteg, Lina. Debutantpris till Khemiri, Dagens Nyheter Online, 05.03.2004, https://www.dn.se/arkiv/kultur/debutantpris-till-khemiri. (20.10.17)

Khemiri, Jonas Hassen. Et øye rødt. Gyldendal Forlag, Oslo, 2005.

Kongslien, Ingeborg, Migrant or multicultural literature in the Nordic countries, in Grønn, Jenny Fossum (ed.). Nordic Voices. Literature of the Nordic Countries. Nordbok, Oslo, 2005, http://www.eurozine.com/migrant-or-multiculturalliterature-in-the-nordiccountries/ (20.10.17)

Moretti, Franco. Conjectures on World Literature, in: Christopher Prendergast (ed.). Debating World Literature. Verso, London; New York. 
Seyhan, Azade. Writing outside the nation. Princeton University Press. Princeton; Oxford, 2000.

Sørbye. Camilla. Anmeldelse av Romeo Gill i Drammens Tidende, in Drammens Tidende, 14.07.2011, https://lesesirkler.wordpress.com/2011/o7/18/anmeldelse-av-romeo-gill-idrammens-tidende/ (20.10.17).

Vaagan, Robert. Bibliotekene og det Flerkulturelle Norge. En delrapport $i$ Bibliotekutredningen 2006. ABM-Utvikling, Oslo, 2005.

Wallerstein, Immanuel. World-Systems Analysis. An introduction. Duke University Press, Durham; London, 2004. 